\title{
Ticks (Amblyomma gervaisi and A. pattoni) on Indian Rock Pythons, Python molurus (Linnaeus 1758), from Himachal Pradesh, India
}

\author{
Gaurav Barhadiya
}

Department of Environmental Studies, University of Delhi, New Delhi, Delhi-110007, India (Gaurav7wild7@gmail.com)

$\mathrm{R}^{\mathrm{e}}$ eptiles are hosts to a number of parasitic organisms ranging from protozoans to arthropods (Frye 1991). Among these, ticks are the most common arthropod group that parasitizes reptiles (Kilingenberg 1993). Ticks are distributed worldwide and primarily found in warm and humid climatic conditions (Auffenberg and Auffenberg 1990). Ticks are a well-known cause of dermatological problems in reptiles and the diseases spread by ticks are a major constraint to animal productivity while causing morbidity and mortality in animals (Ghosh and Nagar 2014). Many ticks in the genus Amblyomma (previously Aponomma) are specific to snakes and lizards (Hoogstraal and Aeschlimann 1982), with 37 of 102 species exclusively parasitizing reptiles (Buczek et al. 2006).

On 5 April 2017, three confiscated Indian Rock Pythons (Python molurus) from Karsog, Himachal Pradesh, India $\left(31^{\circ} 23^{\prime} 00.3^{\prime \prime N}, 77^{\circ} 12^{\prime} 16.6^{\prime \prime E}\right)$ (Fig. 1), were screened for ectoparasites. All visible ticks were collected using sterilized forceps, transferred to vials containing $70 \%$ alcohol, and identified using the key in Sen and Fletcher (1962). After the removal of ticks, the rescued pythons were released into natural habitat.
The three Indian Rock Pythons were infested with a total of 23 ticks (Table 1) identified as Amblyomma gervaisi ( $\mathrm{n}=$ $18)$ and $A$. pattoni $(\mathrm{n}=5)$. Most were near the mouth and cloacal aperture of the snakes.

Ticks in the genus Amblyomma have been previously recorded in southern Asia from wild and captive snakes, including Oriental Ratsnakes (Ptyas mucosa), Indian Cobras (Naja naja), King Cobras (Ophiophagus hannah), Indian Rock Pythons (Python molurus), and Reticulated Pythons

Table 1. Number of ticks (Amblyomma gervaisi and Amblyomma pattoni) recorded from three Indian Rock Pythons (Python molurus) from Karsog, Himachal Pradesh, India.

\begin{tabular}{lcccc} 
Sex & $\begin{array}{c}\text { Length } \\
(\mathbf{m})\end{array}$ & $\begin{array}{c}\text { Weight } \\
(\mathbf{k g})\end{array}$ & $\begin{array}{c}\text { A. gervaisi } \\
(\mathbf{n})\end{array}$ & $\begin{array}{c}\text { A. pattoni } \\
(\mathbf{n})\end{array}$ \\
\hline Male & 2.00 & 3.94 & 5 & 2 \\
\hline Male & 2.27 & 5.30 & 8 & 3 \\
\hline Female & 2.22 & 5.90 & 5 & 0 \\
\hline
\end{tabular}
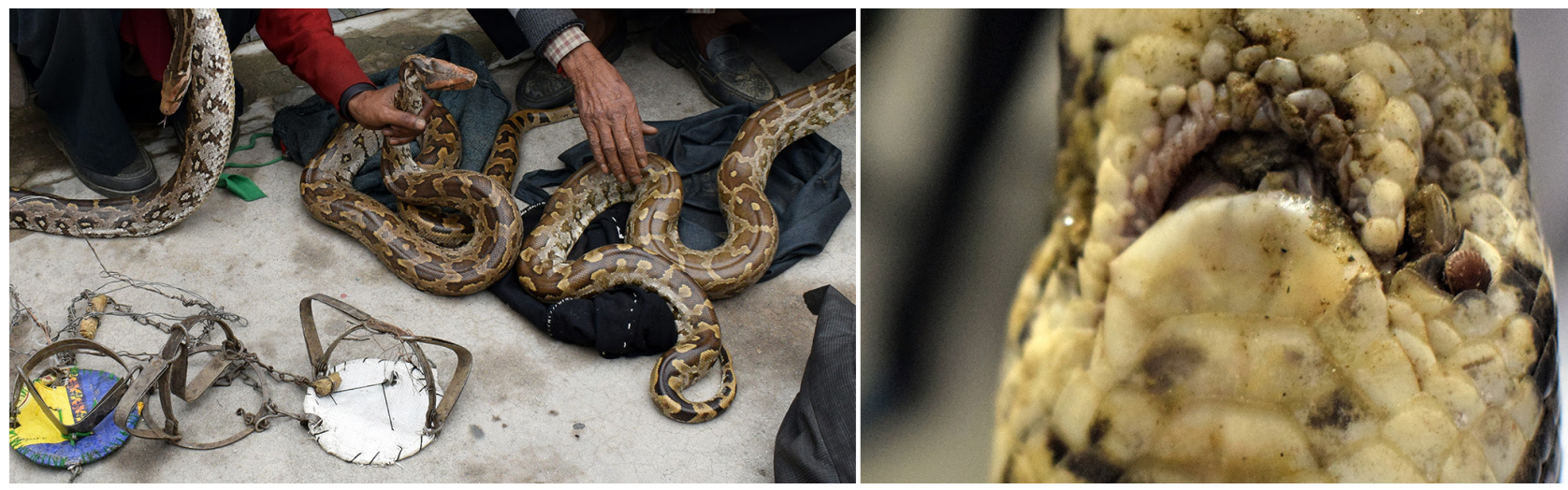

Fig. 1. Three confiscated Indian Rock Pythons (Python molurus) from Karsog, Himachal Pradesh, India (left). A tick (Amblyomma pattoni) adjacent to the cloacal aperture of an Indian Rock Python (right). Photographs by the author. 
(Malayopython reticulatus) (e.g., Rajesh et al. 2015; Pandit et al. 2011). However, to the best of my knowledge, this is the first report of ticks in the genus Amblyomma infecting snakes in the state of Himachal Pradesh.

\section{Acknowledgements}

I thank Jose Louies, Deputy Director \& Chief, Wildlife Crime Control Division, Wildlife Trust of India (WTI), for giving me an opportunity to assist with rescue operations of the Wildlife Crime Control Division (WCCB), Ministry of Environment, Forest and Climate Change, Government of India. I also thank WCCB and the Himachal Pradesh Forest Department for support and encouragement.

\section{Literature Cited}

Auffenberg, W. and T. Auffenberg. 1990. The reptile tick Aponomma gervaisi (Acarina Ixodidae) as a parasite of monitor lizards in Pakistan and India. Bulletin of the Florida Museum of Natural History 35: 1-34.
Buczek, A., K. Bartosik, T. Olszewski, K. Stępień, T. Kubrak, and M. Sałata. 2006. Host specificity of ticks (Acari: Ixodida), pp. 37-54. In: A. Buczek and C. Błaszak (eds.), Arthropods: Epidemiological Importance. Koliber, Lublin, Poland.

Frye, F.L. 1991. Applied clinical nonhemic parasitology of reptiles, pp. 281325. In: F.L. Frye (ed.), Biomedical and Surgical Aspects of Captive Reptile Husbandry. Krieger Publishing Co., Malabar, Florida.

Ghosh, S. and G. Nagar. 2014. Problem of ticks and tick-borne diseases in India with special emphasis on progress in tick control research: A review. Journal of Vector Borne Diseases 51: 259-270.

Hoogstraal, H. and A. Aeschlimann. 1982. Tick-host specificity. Bulletin de la Société Entomologique Suisse 55: 5-32.

Klingenberg, R.J. 1993. Understanding Reptile Parasites. The Herpetocultural Library Series. BowTie Press, Irvine, California.

Pandit, P., R. Bandivdekar, G. Geevarghese, S. Pande, and O. Mandke. 2011. Tick infestation on wild snakes in northern part of Western Ghats of India. Journal of Medical Entomology 48: 504-507.

Rajesh, N.V., K.D. Rajesh, M.G. Jayathangaraj, M. Raman, and R. Sridhar. 2015. Parasitic fauna of captive snakes in Tamilnadu, India. Asian Pacific Journal of Tropical Disease 5: 930-934.

Sen, S.K. and T.B. Fletcher. 1962. Veterinary Entomology and Acarology for India. Indian Council of Agriculture Research, New Delhi, India. 